\title{
Accounting knowledge in innovative firms - direct contacts with external auditors for strategic actions
}

\section{Marita Blomkvist*}

Department of Business and Administration, School of Business Economics and Law, University of Gothenburg,

P.O. Box 610,

Gothenburg SE-405 30, Sweden

Email: Marita.Blomkvist@handels.gu.se

*Corresponding author

\section{Jeaneth Johansson}

Entrepreneurship and Innovation/School of Business,

Engineering and Science,

Luleå University of Technology/Halmstad University,

Luleå SE-971 87, Sweden

Email: Jeaneth.Johansson@1tu.se

\section{Malin Malmström}

Entrepreneurship and Innovation, Luleå University of Technology, SE-971 87 Luleå, Sweden

Email: Malin.Malmstrom@1tu.se

\begin{abstract}
Managers' use of auditors in decision processes is well known in the accounting literature, but little is known about owner-managers in innovative firms and their acquisition of accounting knowledge through direct contacts with external auditors. We conducted a multiple embedded study of exploratory character based on 21 interviews with owner-managers and external auditors connected to six innovative firms. We show that owner-managers in innovative firms apply informal management control in early phases of the innovation process and thus also rely heavily on external auditors for such purposes. However, management's acquisition of accounting knowledge may contribute over time to the development of a more formalised control system as their competence increases. This study suggests that a competence-based view may be useful for understanding the role of accounting and external auditors in innovative firms' management control systems.
\end{abstract}

Keywords: accounting knowledge; external auditor; innovative firm; strategic action.

Reference to this paper should be made as follows: Blomkvist, M., Johansson, J. and Malmström, M. (2016) 'Accounting knowledge in innovative firms - direct contacts with external auditors for strategic actions', Int. J. Managerial and Financial Accounting, Vol. 8, Nos. 3/4, pp.209-229. 
Biographical notes: Marita Blomkvist is an Assistant Professor in Accounting at University of Gothenburg. Her research in financial accounting and management accounting revolve aspects related to financial accounting quality and the use of accounting information across types of SMEs. She has professional working experience in the corporate business as an Auditor and Consultant.

\begin{abstract}
Jeaneth Johansson is an Associate Professor in Entrepreneurship and Innovation at Luleå University of Technology and Guest Researcher in Accounting at Halmstad University. Her research in financial accounting and management accounting revolve behavioural, social and organisational aspects related to financial decision-making, disclosure and business model management.

Malin Malmström is an Associate Professor in Entrepreneurship and Innovation at Luleå University of Technology. Her research interests are related to cognitive foundations and competences in venture's innovation management and in financiers' financial decision-making.

This paper is a revised and expanded version of a paper entitled Accounting Knowledge in Innovative Firms - Direct Contacts with Auditors for Strategic Actions presented at the annual American Accounting Association meeting (AAA), Chicago, IL, August 8-12, 2015.
\end{abstract}

\title{
1 Introduction
}

This paper seeks to explore our understanding of owner-managers in innovative firms and their acquisition of accounting knowledge through direct contact with external auditors. The focus is particularly on owner-managers' competence acquisition and the value added by external auditors in guiding strategic actions in innovative high-growth firms. Innovation and growth are important both to firms and society; firms need them to survive, renew their businesses and become profitable, and society needs them to create job opportunities and achieve economic development (Acs et al., 2004; Birch, 1979; Henrekson and Johansson, 2010). In this paper, innovative firms are defined as firms that are generating and/or adopting (or using) new ideas or behaviours (Gopalakrishnan and Damanpour, 1997) that lead to significant growth in terms of sales or assets. Prior research indicates that high-growth firms tend to be more innovative compared to nongrowing firms (Del Monte and Papagni, 2003; Hölzl, 2009). It is widely recognised that innovative high-growth firms need competent and informed management in order to manage the high level of uncertainty they face and to succeed. We also know that external auditors play a central role in firms' management of information, particularly in disclosing and legitimising firm information to stakeholders (Clarkson and Simunic, 1994). In spite of this, the understanding of external auditors' contribution to accounting knowledge in managerial work in the context of entrepreneurship and innovation is limited (Davila, Foster and Oyon, 2009; Hall, 2010).

Accounting information has often been criticised in the entrepreneurship literature as not useful for decision-making, since innovation is about the future, while accounting information primarily looks at the past (Collier, 2005; Davila, 2000; Gibson, 1992; Young, 1987). However, recent entrepreneurship studies in the innovation context reveal 
that accounting information is central for managers in innovative firms (Davila, 2005; Davila, Foster and Oyon, 2009). Managers in these firms belong to the core group of users of accounting information, drawing on financial reports and regulated audits as they carry out their work in uncertain environments. This information helps them make informed decisions, develop strategies and convince stakeholders (Healy and Palepu, 2001; Power, 2003). They use and assess a broad variety of accounting and nonaccounting information. For instance, they may use historically oriented accounting information complemented by non-accounting future-oriented information and measures when assessing the potential of a proposed future initiative (Cooper and Morgan, 2008). Accounting information is also important for owner-managers when they are mitigating problems with asymmetric information between the firm and the external stakeholders to support statements about finances and investments (Rossi, 2014). For internal purposes, accounting information helps managers identify good projects and increase investment efficiency (Chen et al., 2011; McNichols and Stubben, 2008). Prior research shows that a wide range of accounting information is important for managers' internal decisionmaking, for instance, for evaluating innovative projects and for stating criteria for go/no go decisions throughout development processes. Further, accounting information tends to be of particular importance in early phases of development processes for anticipating information on the environment (Bennett and Robson, 1999; Collis and Jarvis, 2002; Hart and Hultink, 2003; Kirby and King, 1997). Accounting information is thus a central part of internal decision-making and strategic actions for innovative firms' management, as part of the management control. Strategic actions may involve, for example, venture's investments, entry into new markets and product development carried out in line with the venture's innovative strategy (Ozcan and Eisenhardt, 2009). Such management control may be of a more or less formal or informal design (Davila, 2000). Nevertheless, the literature on managers' use of accounting information for strategic actions as part of management control in the field of innovation is still sparse (Davila, Foster and Oyon, 2009; Hall, 2010; for a review of management control, see Maggina, 2009). Prior studies show that managers use a large number of information sources to access accounting and non-accounting information needed for strategic actions and for developing their own knowledge about accounting information for use in specific situations. It is known that innovative firms can benefit significantly from using both internal information sources (Sanchez, Heene and Thomas, 1996; Sanchez and Heene, 1997a, 1997b; Souitaris, 2002) and external information sources (Oviatt and McDougall, 1993; Tidd, Bessant and Pavitt, 2005; Love and Roper, 2002), and that competence acquisition is an important issue in innovative firms (Camuffo and Comacchio, 2005; Lowe and Taylor, 1998; Tzokas, Carter and Kyriazopoulos, 2001). Information is expressed in both written and verbal forms, for example, through firm financial reporting and discussions with auditors or external accountants. Studies show that managers' interaction with information through verbal conversations is a central part of how accounting information becomes implicated in the managerial work (Hall, 2010; Jönsson, 1998). Managers' direct contacts with auditors are one such information source suggested to bring new knowledge to the managers and their management control (Clarkson and Simunic, 1994; Johansson, 2007). We consider direct contacts to include all contacts between the innovative firm and the auditors; such contacts may include one-to-one meetings, group meetings, phone calls, emails or other forms of communication. Nevertheless, understanding of external auditors' contribution to owner-managers' accounting knowledge for strategic actions in 
the context of innovation and management control is limited (Davila, Foster and Oyon, 2009; Hall, 2010).

Prior research shows that managers use accounting information in different ways, depending on both personal factors and firm circumstances. For instance, their use of accounting information is determined by their education level and comfort in interpreting such information (Shawn and Van Auken, 2013). In line with this, studies show that accountants are rated as the most used external source of advice for small firms and that they are important in situations where firm management lack finance and accounting skills (Bennett and Robson, 1999; Berry, Sweeting and Goto, 2006; Blackburn and Jarvis, 2010; Halabi, Barrett and Dyt, 2010), and where, for instance, financiers need to be convinced about a venture's investment potential (Fellnhofer, 2015; Paananen, Renders and Blomkvist, 2016). In such situations, an external auditor (Certified Public Accountant, CPA) can translate and make the accounting information from financial reporting understandable to the owner-manager (Marriott and Marriott, 2000; Perren and Grant, 2000). Prior studies also show that managers' use of financial statements in decision-making is affected by whether firms have their financial statements prepared internally or externally. Auditors play a central part in firms that rely on external preparation of financial statements (Carraher and Van Auken, 2013). This may be directly connected to accounting knowledge and the design of innovative firms' management control. Accounting knowledge may thus be lower in firms that rely on external preparation than in firms that prepare their own financial statements, and the management control can thus also be expected to be less developed in firms that rely on external preparation. We believe that some significant issues have been left unexplored. For example, scholars have not identified what key accounting knowledge ownermanagers in innovative firms may gain access to from direct contacts with external auditors to guide them in their strategic actions, nor have they focussed on potential benefits external auditors may have for innovative firms' competence acquisition.

This study is based on data collected from 21 interviews with external auditors and owner-managers in six high-growth innovative firms and also on collected financial documents. This exploratory case study contributes to knowledge about how ownermanagers in innovative firms acquire accounting information and knowledge that can be used, for example, for strategic action and decision-making. Using an inductive qualitative research design, we noticed the relevance of direct contacts between ownermanagers in innovative firms and external auditors, where management acquire competence from direct contacts with external auditors, thereby developing competitive advantages. We explore the context of direct contacts between innovative firms and auditors as well as the content of information and knowledge acquired through such contacts. Our research is also motivated by the need to understand external auditors' contribution to owner-managers' accounting knowledge for strategic actions in the context of innovation and management control. Innovation and growth are important for firms to survive, renew their businesses and become profitable and for society to create job opportunities and achieve economic development (Acs et al., 2005; Birch, 1979; Henrekson and Johansson, 2010). Given that the literature on managers' use of accounting information for strategic actions as a part of management control in the field of innovation is still sparse (Davila, Foster and Oyon, 2009; Hall, 2010), the results also contribute to further understanding of the role of accounting information in high-growth innovative firms where opportunities are explored and exploited. 
The remainder of the paper is organised as follows: The next section provides the theoretical background. Thereafter, a brief literature review is presented, followed by the research methodology. The findings and interpretations are then presented. The final section contains a discussion and conclusion.

\section{Theoretical background}

In terms of theory, we build on the competence-based view of the firm (Hamel and Heene, 1994; Hamel and Prahalad, 1990; Sanchez, Heene and Thomas, 1996; Sanchez and Heene, 1997a, 1997b), which emphasises the identification of ways in which firms can obtain competitive advantage through a superior ability to coordinate flows of intellectual assets and other resources. In this view, building competitive advantage is a contest for the acquisition of competences (Malmström and Wincent 2012; Malmström, Wincent and Johansson, 2013) This perspective acknowledges managers' knowledge about what kinds of assets and capabilities, business alternatives and existing competences are important in order to consider what kinds of competences the firm should start to acquire (Sanchez, Heene and Thomas, 1996). The stocks and flows of a firm's tangible and intangible assets are organised according to the firm's strategy, which is the organisation's operative rationale to achieve its goals, coordinated by a firm's management processes to build and leverage competences. In the small firm, this means that competence acquisition is motivated by managers' perceptions of strategic gaps between the firm's current stocks and flows of assets and capabilities and the stocks and flows they believe they need to achieve the firm's goals in its competitive environment (Malmström, 2014; Malmström, Johansson and Wincent, 2015). Managerial perceptions of strategic gaps therefore lead to changes in each firm's strategic actions (Sanchez, Heene and Thomas, 1996; Sanchez and Heene, 1997a, 1997b). We argue that the auditor is essential in shaping managers' perceptions and strategic actions in the firm. We build on the reasoning that although managers may need mentoring and support from sources of external competence to orchestrate a rapidly growing firm, they may risk losing their competitive edge if they involve the 'wrong' competence and risk leakage of competitive secrets. While they need external competence support, trust in the auditor both as a competent advisor and as a non-competitive institution becomes a key source of competence for the manager to make the business thrive.

Although it is known that smaller firms can benefit significantly from using internal sources (Sanchez, Heene and Thomas, 1996; Sanchez and Heene, 1997a; 1997b; Souitaris, 2002) and external sources of expertise (Love and Roper, 2002; Oviatt and McDougall, 1993; Tidd, Bessant and Pavitt, 2005), and that competence acquisition is an important issue in firms (Camuffo and Comacchio, 2005; Lowe and Taylor, 1998; Tzokas, Carter and Kyriazopoulos, 2001), we believe that some significant issues have been left unexplored. For example, scholars have not listed what knowledge innovative firms may gain access to from auditors to guide their strategic actions, nor have they focussed on potential benefits auditors can offer in relation to innovative firms' competence acquisition. 


\section{Literature review}

\subsection{Strategic actions in innovation - management control and accounting}

This paper focusses on strategic action where entrepreneurship includes a process, from exploration to exploitation (March, 1991) of opportunities in resource, capital and product markets. Information is highly important for such actions (Kirzner, 1997; Shane and Venkataraman, 2000; Venkataraman, 1997). Information is needed for decisionmaking and strategic action, both internally and externally oriented. For example, firms that are in the process of exploring and exploiting opportunities typically need to acquire external resources; and for this, they need to convince the external providers of their innovation potential, which they do by disclosing information on future potentials. Innovative firms are dependent on gaining access to financing from external investors, setting up an agency relationship (Rossi, 2015). These control problems relate to the corporate governance of the firm, a core part of the firms' strategic actions (Hakim and Omri, 2009).

Information is also useful for internal purposes when entrepreneurs explore and exploit their innovation opportunities. Davila, Foster and Oyon (2009) argue that management control is a fundamental aspect of entrepreneurship and innovation. The authors highlight the relevance of management control for actively managing different phases of firms' innovation processes. The nature of such control needs to be adjusted to the specific context. For instance, more information control may be used in early innovation phases, whereas more formalised management control may be developed throughout the innovation processes to deal with different challenges as they come up (Davila, Foster and Oyon, 2009). Ylinen and Gullkvist (2014) illustrate how organic control in terms of informal control and open channels of communication is an important form of control in exploratory innovations. They also show that organic control enhances performance in exploitative innovations. Managers' need for information and their need to acquire accounting knowledge may hereby be expected to differ between firms and between different phases in the innovation processes. We believe that the auditor can be a main external actor who can discuss economic activities and provide important knowledge to the manager in the innovative firm that can then be used guiding strategic actions in the innovation process. For example, the manager can gain access to knowledge from the auditor about accounting information that is important to communicate to external stakeholders or information that is important for informal management and control of innovations.

\subsection{Managers' use of accounting information}

Owner-managers in innovative firms more or less explicitly work with strategic decisionmaking guiding future actions. In this work, they need a mix of accounting information, such as 'hard' information, in the form of numbers, and 'soft' non-accounting information that may be used for making sense of the business; once that occurs, that information can then be transformed into accounting numbers (i.e. hard information). As such, accounting and non-accounting information form the framework of accounting knowledge. Previous studies, for instance, show that managers primarily use accounting information to develop knowledge of their work environment rather than as an input into 
specific decision-making scenarios (Hall, 2010). A survey study by Laitinen (2009) on Finnish CEOs in the manufacturing industry also shows that accounting information, especially profitability information, is highly appreciated by the CEOs. Their study also shows an information gap concerning new products related to non-accounting information. Findings in the field of management control suggest that product innovation enhances financial performance when accounting information is used in budget decisions as a planning mechanism (Dunk, 2011). In contrast, Dunk also finds that when the emphasis is on using budgets primarily as a control mechanism, innovation fails to influence performance. Further, financial reports constitute just one source of information managers can use to get things done. Also, as managers talk to others, accounting information becomes implicated in managerial work. The use of such information may be connected to informal, social forms of control rather than explicit and formal management control (Collier, 2005).

\section{Methodology}

We conducted a multiple embedded case study of explorative character based on interviews with external auditors and owner-managers in six innovative firms in Sweden ${ }^{1}$ and studied internal and external documents such as financial annual reports and audit reports (Yin, 1994). We asked the managers of three audit firms to identify innovative high-growth firms among their clients. Six high-growth innovative firms from both manufacturing and service industries and with different owner structures were chosen for an in-depth study. We sampled innovative firms in terms of both product and service innovation and also firms with different owner profiles, owner-management experience and owner-managers' education levels so as to get extensive and diverse examples of external auditor and owner-manager relationships and owner-managers' uses of audit information. Choosing extreme cases is appropriate in an open-ended exploratory study (Seawright and Gerring, 2008). This methodological approach limits the extent to which results can be generalised. However, it seeks to provide sufficient understanding of the issue.

A qualitative approach is particularly suitable for theory development in situations such as the present one, where key themes in managements' competence acquisition through direct contacts with external auditors have been poorly developed (Eisenhardt, 1989a, 1989b; Gibbert, Ruigrok and Wicki, 2008). We collected qualitative data by interviewing the owner-manager and the external auditor for each innovative firm. The interviews were held in connection to the time when the annual report and audit were finished, and they were followed up with a second interview a year later. We chose semistructured interviews to capture in-depth, detailed information. To meet the aim of this paper, the interviewees were allowed to speak rather freely. The first set of interviews commenced initially with general questions about the external auditors' and ownermanagers' background and about the innovative firm. Thereafter, interviews were focussed around a set of questions about the most recent annual financial report, the audit report, discussions between the external auditor and the owner-manager, useful information around decision-making and the innovation process itself. The second set of interviews focussed on managerial actions and potential benefits of external auditors' competence. All interviews were conducted face-to-face, documented in detail, recorded 
and transcribed. Data from financial reports and audit reports where used primarily for understanding the context and for developing the interview instrument.

Our data analysis involved several steps with the purpose of identifying knowledge acquired through managements' direct contacts with external auditors and what potential benefits such direct contacts may have for innovative firms' competence acquisition. Initially, in what could be considered the first step, we followed the microanalysis recommendations outlined by Strauss and Corbin (1990) to engage in a 'line-by-line' examination of transcribed text. In doing so, we identified several concepts referring to characteristics of the communication, which we divided into categories of

1 context for communication

2 content of information and knowledge acquired

3 benefits of acquired information.

To balance richness and direction in this first step, we guided our coding process with the questions: How are the direct contacts carried out? How are direct contacts used by owner-managers? What knowledge and what benefits do innovative firms acquire from auditors through direct contacts? These questions allowed us to identify key characteristics in context and content of information acquisition through external auditors. This enabled us to focus on the benefits acquired through the direct contacts and to elaborate upon such benefits, and on how acquisition of information and knowledge are ultimately used for fostering competitiveness in innovative firms. In the second step, we identified the relevance of using the competence-based perspective for analysing findings and also carried out further analyses in line with this view.

Initial coding was carried out individually by the researchers involved, based on the transcriptions, in order to identify themes and constructs. In this coding, we scanned the data for material about information signal search, information signal adoption and justifications/rationalisations for decisions. We continued by comparing and discussing the coding in the research group. Involvement of all researchers in the coding and analysis ensured that different perspectives would be captured in the interpretation of data, making a more objective view possible (Eisenhardt, 1989a, 1989b; Eisenhardt and Graebner, 2007; Miles and Huberman, 1994). We noticed high consistency, which we believe strengthened the internal validity (Gibbert, Ruigrok and Wicki, 2008).

When coding, we counted the number of occasion concepts attached to the core groups of context and content in the discourses were used (Denzin and Lincoln, 2000), and we used tables to compare and categorise the identified concepts (Miles and Huberman, 1994). Consistent with recommendations, identified patterns in empirical findings were compared to predicted patterns found in the literature (Denzin and Lincoln, 2000; Eisenhardt, 1989a, 1989b).

We outlined analyses of owner-managers' acquisition of accounting competence and roles played by accounting information in innovative firms. We hereby identified and labelled a set of knowledge acquired and benefits gained by innovative firms through direct contacts with auditors. The types of knowledge acquired are 'comprehensive knowledge', 'diagnostic appraisal knowledge', 'contemporary business intelligence' and 'innovation investment impact knowledge', and benefits gained are 'accelerating information processing' and 'facilitating external legitimacy' of the firm's stocks and flows. The analyses are based upon analytical generalisations, which allowed us to compare the identified groups of owner-managers in innovative firms with the literature 
on accounting and audits as well as the competence-based view. Development of the analyses was carried out through iterations between inductive conceptualisation and the literature, which allowed the researchers to sharpen construct definitions and patterns between the categories identified (Eisenhardt and Graebner, 2007; Ozcan and Eisenhardt, 2009). This approach strengthened the internal validity of the findings and contributed to the emergent theory (Yin, 1994). We therefore believe that the processes identified can provide general insights, although we are aware of the limitations of our approach.

The empirical data are presented to provide the diversity of how financial reporting and the audit are discussed between the auditor and manager of the innovative firm and how this information is then used to make business decisions related to the innovation process. The empirical findings are illustrated with quotations.

\section{Findings on knowledge gain and potential benefits of auditors}

\subsection{Knowledge innovative firms may gain access to from auditors}

Our qualitative data analysis reveals that the managers used direct contacts with external auditors to gain access to information and knowledge. We identified characteristics of these direct contacts in terms of

1 type of direct contacts, that is, 'context for communication'

2 content of information and knowledge acquired.

Direct contacts usually took place in contexts such as board meetings, different types of annual meetings, such as with employees, and lunches where management had the opportunity to pose questions and discuss the accounting information with the auditors. Information and knowledge were acquired through external auditors' pedagogical presentations and their translations of the annual report information as well as additional detailed financial reports prepared by the auditors. External auditors were also used for internal legitimising of accounting information, for example, for the purpose of management control. The following quotations illustrate the context of direct contacts in board meetings and content of information and knowledge acquired through such meetings:

\footnotetext{
"The auditor explains the financial outcome and provides detailed information that captures financial data for several firm years."

"We go through all the records and compare with previous years, [to see] what has changed."

"We ask about what underlying items are included in a separate accounting record ... what is behind ..."
}

Yet another owner-manager said that the external auditor was invited to give a pedagogical explanation of the interim reports and discuss the profit outcome compared to both the budget and the previous year's outcome. Direct contacts with external auditors were also made for purposes other than to acquire pedagogical translations or additional report information. This was the case, for instance, when the company had internal accounting competence and where the owner-manager had academic competence and long-term owner-management experience. In such cases, managers invited the auditors to 
lunch when the audit was finished to finalise the audit process. This was more or less for final legitimisation of the firm's own work. One owner-manager said:

"We have very good internal accountants so there were not many questions from the auditor."

Another context of direct contacts identified was annual staff meetings. External auditors were used by owner-managers at such occasions to educate employees and increase the competence base of the staff for the innovative firm to become more competitive. One owner-manager said that every year he invites the external auditor to give a pedagogical presentation since it is important for the employees to understand how to reach the firm's goals, for example. In this firm, all employees had a bonus program related to the annual result. The owner-manager expressed his own and the internal accounting department's lack of needed competence in accounting and also how the external auditor helped him communicate with the staff, for instance, in legitimating information:

"He explains exactly where the money goes; I would have said the same, but I learn. I'm no accountant but I learn."

These instances of empirical evidence illustrate how the auditor can be an important source of knowledge, breaking down complex accounting information into accessible and assessable pieces of information for management about the firm's stocks and flows. Such knowledge which innovative firms may gain through the auditor thus supports innovative firms in identifying strategic gaps in their business ventures, leading to important changes in strategic actions. We label this access 'comprehensive knowledge'.

Owner-managers also used external auditors for quality assurance purposes and to improve the management control system. The owner-managers acquired knowledge on how to make improvements. Most of firms had limited or almost non-existent formal management control systems, and the owner-managers had no academic education. The external auditors in these firms provide additional specified financial information about the firm, including comparisons in the form of ratios, graphical and figures, and they discuss this management accounting information with the owner-managers. The ownermanagers, for instance, highlighted external auditors' comments on strengths and weaknesses in the firm management control system and on the quality of the annual report.

Some examples of weaknesses in management control systems described by interviewed auditors include the following:

$$
\begin{aligned}
& \text { “... need to follow-up revenues at customer level" } \\
& \text { “... expense categories "other costs" need to be checked" } \\
& \text { “... assets classified as inventories require better control." } \\
& \text { “... expenses related to R\&D require better control." } \\
& \text { “... there is a need for better internal reports." }
\end{aligned}
$$

As the above quotations show, the auditors argued that there was a lack of formal management control system in the audited firms. The auditor explained the audit purposes and the auditor shouldered the responsibility for the manager and the board members. Next, the auditor provided a summary of the audit. This summary focussed on the valuation of R\&D and accounts receivable at the year end. The auditor emphasised the uncertainty about the firm's continued operations and the need for new funding. 
Further, the auditor informed the manager and the board members about weaknesses in the firm's information system. For example, he commented on the quality of operating accounting and highlighted the need for improvements. The auditor issued a qualified audit report in this innovative firm. These examples illuminate how an auditor may contribute important knowledge to an innovative firm about its stocks and flows and thus help the firm identify strategic gaps in its business ventures that lead to important changes in strategic actions. We categorise this as access to 'diagnostic appraisal knowledge'.

Some comments captured at the interview with one auditor were as follows:

"The company must establish and ensure a detailed project accounting that enables development cost to be allocated to the product or to a product group."

"It is important to ensure that the company does not activate the market costs, supply costs or other type of costs that are related to products for production."

"Quality of accounting needs to be improved and be based on business events and not be swayed by a cash basis."

"The annual report must include significant events that have occurred after the year-end."

Generally, the interviewed managers found the audit meeting and information from the auditor to be important. Owner-managers repeatedly emphasised how the auditor helped management identify strategic gaps in the firm's stocks and flows that helped them make important changes in their strategic actions. The owner-managers' discussions with the auditors tended to be of particular importance in situations where the firm outsourced the accounting function and the owner-manager had no academic education. In such situations, they both needed knowledge of accounting and to assure for quality of the annual report. Statements such as following illustrate owner-managers' use of external auditors for management control and internal quality control:

"You want it to be genuine and correct ... and have someone who comes and takes a look so that we have good procedures ... so it's worthwhile I think."

"We found out that this was just a 'trash account' ... we have restructured so that expenses are matched on a project."

"Our accounting function is outsourced, so it is important to me that I have an auditor who writes an internal report ... so that we know ... he dares to be critical ... and suggests improvements."

Owner-managers also used external auditors to acquire knowledge about forthcoming changes in regulations and how to anticipate and deal with such changes. We label such knowledge as access to 'contemporary business intelligence'. The owner-managers, for instance, highlighted discussions on new regulations, such as accounting and tax rules, that may affect their businesses. Owner-managers also used discussions with external auditors to increase their knowledge of potential effects on their own private economy. Discussions also focussed on increasing knowledge about political factors that underpin current regulations and political factors that may cause regulative changes, for instance, due to new governmental regimes. The owner-managers acquired knowledge on environmental factors through the external auditor. In this role, accounting information was helpful for the owner-managers' knowledge development to prepare for unknown future decisions and activities (Hall, 2010). This was expressed as follows: 
"World coverage ... he keeps track of new regulations ... what has changed ... how the politicians act today and what we need to be aware of in the future."

"I discuss with my auditor accounting rules related to R\&D, my salary and future dividends; how our firm is affected by the regulations today and in the future."

Direct contacts with external auditors were also used by owner-managers for acquiring more detailed knowledge about specific situations and for developing scenarios on consequences for their firms' current and future status, for example, in terms of accounting numbers. Resources are needed in all phases of firms' innovation, from exploration to exploitation, and managers experience that they need to keep track of the situation throughout these phases. We refer to this as access to 'innovation investment impact knowledge'. Situations with strategic investment decisions are common and also critical for firm innovation, and such situations require accounting knowledge in order to assess investment potential and opportunities. In line with this, one owner-manager expressed that:
"He [the auditor] explains how an investment will affect the financial report in the future. We have a couple of projects that cost us money ... we have programme development that costs us money, and we follow up these expenses very carefully; it feels like a black hole ..."

One aspect of the direct contacts is the frequency of the contacts. The owner-managers typically met the external auditors and had discussions with them a number of times per year. It was common for them to meet the external auditor three or four times a year. Such meetings helped the owner-managers and the external auditors get to know one another. The meetings had various purposes. One typical meeting took place just before the final audit meeting and was held before the board meeting where the external auditor would present the audit report. The owner-manager and external auditor then focussed the discussion on the written audit report that the auditor would be presenting to the board. Issues such as doubtful debts, valuation of R\&D, management development needs and uncertainty of continuing operations were highlighted and further discussed between the owner-manager and the external auditor. This helped the owner-manager acquire knowledge about the situation before external disclosure.

An additional aspect of the context of meetings that influenced the owner-managers' acquisition of knowledge through direct contacts with external auditors was the aspect of trustworthiness. Where the owner-managers worked with specific auditors for a long time, they got to know them and developed relationships with them. The owner-managers in these firms trusted the external auditors' competence and also relied on the advice and information acquired through the direct contacts with these auditors. One example of this is an owner-manager who expressed that:

\footnotetext{
"It was something that was made to our accounts that pulled down our profit ... I don't know exactly, but it was something about work in progress ... we rely $100 \%$ on our auditor, we never ask another advisor. It's like going to the doctor; I feel I rely equally on the auditor and the doctor, almost more on the auditor, actually ..."
}

To sum up, the statements above suggest that the acquisition of external auditors' competence is essential for owner-managers' strategic actions both internally and externally. We refer to such auditor knowledge as owner-managers' access to 'comprehensive knowledge', access to 'diagnostic appraisal knowledge', access to 
'contemporary business intelligence' and access to 'innovation investment impact knowledge'. Owner-managers highlight access to accounting knowledge from external auditors through verbal forms of communication, typically in connection to written accounting reports. This knowledge was characterised as, for instance, information for certain decision-making purposes as well as knowledge of their work environment in general, and knowledge and understanding related to unknown future actions (Hall, 2010; March, 1991). The context of owner-managers' direct contacts with auditors is characterised by the aspects such as the purpose of the contacts, which may have both external and internal orientations, the type of meeting; where, when and how the meeting taking place; and who participates in them. Such aspects also illustrate the broad scope of accounting competence acquired through external auditors.

\subsection{Potential benefits of direct contacts with auditors for innovative firms' competence acquisition}

Potential benefits acquired through owner-managers' direct contacts with auditors were briefly identified below and will now be further elaborated on. The owner-managers' use of direct contacts with external auditors led to increased knowledge of firm information and enabled the owner-managers to comprehend the financial reports, firm investment and the effects of the investment (cf. Baum and Silverman, 2004; Bouwman, Frishkoff and Frishkoff, 1987). Innovative firms' use of auditors evidently facilitated their own acquisition of competence, in the sense that direct contacts with auditors led to owner-managers' own competence development, which enabled them to make more informed decisions for strategic actions and continue to build their competitive advantages. We label such benefits as 'accelerating information processing' of the firm's stocks and flows. Statements such as the following illustrate how the owner-managers continually increased their accounting knowledge and became able to interpret the information content of the financial reports through the recurring direct contacts with external auditors:

\footnotetext{
"My financial skills have improved over time."

"Every year we have an annual meeting with our auditor and that is good ... It's thanks to all the discussions with the auditor that I have learned ... every time we meet I learn something new ... then everything changes ... but that is how you learn."

"The auditor speaks their language [accounting language] but translates it so I can understand."

"The audit meeting helps me to understand the financial outcome."
}

It was obvious that owner-managers had direct contacts and discussed with their external auditors before planning and taking strategic actions in the firm. They perceived that they acquired broader firm and accounting competence that help them make more informed decisions. More specifically, owner-managers use accounting and audit information to develop knowledge as an input into specific decision-making scenarios. The external auditors also advise owner-managers based on the financial statement information. The following statements illustrate owner-managers' perceived benefits from acquiring such accounting and audit information from the external auditors: 


\begin{abstract}
"We are aware of the annual results three or four months before year-end; however, we do not take investment decisions before the annual report is discussed at the audit meeting, when we really know."

"When I have an essential new investment to make, then I will wait and make the final decision after the audit meeting."

"After the discussion with my auditor I took the decision to liquidate one of the firm's subsidiaries and to sell another subsidiary."
\end{abstract}

The benefit of increased legitimacy for management through the audit as such but also through the direct contacts with external auditors is evident from the owner-managers' perspective. Through the external auditors, management gains legitimacy - in the boardroom and at the general meetings, and in the eyes of other owners and stakeholders such as financiers, potential customers, media and employees. This acquired legitimacy also enables management to respond to the expected code of conduct and to decrease suspicions of moral hazard. The auditor can thus be important for acquisition of intangible resources such as legitimacy and thus add to the firm's stock of intangible resources and facilitate relationship building with other crucial actors for maintaining innovation and a high-growth strategy. We categorise such benefits stemming from auditors as 'facilitating external legitimacy'. The external auditors appear to be critically important to the managers as trustworthy partners who can provide access to needed resources. This is illustrated by statements such as the following:

\footnotetext{
"The annual report is very important ... I feel that I have a huge responsibility to the owners ... those who own shares now and also for potential shareholders $\ldots$ and shareholders who sold out ... I want to be able to look them in the eye and say that everything is correct in the company ... the information is correct $\ldots$ and also be sure that we have no unfair fees or any irregularities ... the auditor is very important for the company."

"He was helpful when I was discussing the level of cost of debt with my new bank contact."

"It took me a couple of years until I realised how important the annual report was for the stakeholders ... media, competitors ... to be invited to different events ..."

"One of our employees asked me where all the money goes ... I said that he was implying that I and the other owners were taking the money from this company [and sending it] to another company ... then I said that we would never do that; this company is a subsidiary ... I think many of our employees have the same conception ... therefore, it is so important to have an auditor."
}

In sum, it is evident that owner-managers in innovative firms acquire benefits in terms of accounting knowledge and legitimacy from their direct contacts with external auditors, which we refer to as 'accelerating information processing' and 'facilitating external legitimacy'. Such direct contacts are perceived to improve owner-managers' knowledge of the situations, their ability to create scenarios and understand potential consequences and, finally, to make and communicate strategic actions that will meet the approval of vital stakeholders. Findings also show that knowledge acquired from external auditors often compensated for firms' limited or almost non-existent formal management control systems. Owner-managers acquired specific accounting knowledge about the firm through the external auditors' pedagogical discussions and comparisons using, for instance, ratios, graphics and figures to guide managers' strategic actions. Our findings 
support the important role of the auditor for innovative high-growth firms' access to vital knowledge in identifying strategic gaps, leading to changes in strategic actions to secure a thriving stock and flow of firm resources. Our findings additionally pinpoint potential benefits of auditors for innovative firms' competence acquisition. The innovative firms' knowledge acquisition process through the direct contacts with auditors is outlined below (see Figure 1). The conceptualisation captures the competence acquisition, competence development and benefits for firms' strategic actions. As such, it also captures the process of internal and external preparation of financial statements, preparing the firm for strategic action and for communication to external stakeholders.

Figure 1 Innovative firms' value creation through knowledge acquisition from direct contacts with auditors

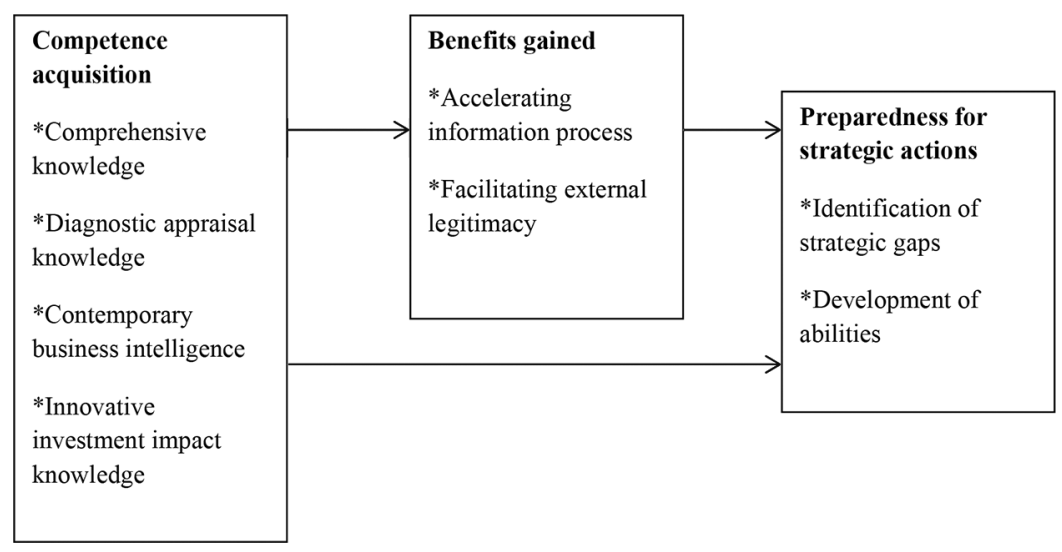

\section{Conclusion and discussion}

The purpose of this study was to explore owner-managers' acquisition of accounting knowledge in innovative firms, and particularly knowledge acquisition through managers' direct contact with external auditors. As such, we contribute knowledge to the neglected context of entrepreneurship and innovation, specifically accounting knowledge in managerial work (cf. Davila, Foster and Oyon, 2009; Hall, 2010). Accounting information was made specific and real for the owner-managers through discussions with external auditors, and the owner-managers continuously learned how to manage the firm by using accounting information.

The accounting knowledge guided the strategic actions in the innovative firms, and the potential benefits of accounting knowledge acquisition through external auditors were evident. First, results on the context for direct contacts provide a diverse set of characteristics determining the owner-managers' acquisition of accounting knowledge. The context of owner-managers' direct contacts with auditors is characterised by the aspects such as the purpose of the contacts, which may have both external and internal orientations; the type of meeting; where, when, and how often the meeting takes place; and who participates in them. The benefits acquired through the owner-managers' direct contacts with external auditors are also evident in terms of knowledge and legitimacy. Accounting knowledge acquired through auditors plays a critical role for owner- 
managers both for their external accounting and management control and for the external communication of accounting information to stakeholders. Innovative firms are exposed to an uncertain and unknown future where owner-managers make investments for innovation to be realised. Accounting information in combination with non-accounting information appears to be a key for prognosticating the future, while management often lack accounting competence that is critical for developing competitive advantages. Auditors play a critical role in guiding strategic actions in innovative firms in line with the accounting logic. These findings align well with prior research showing that auditors play an important role for firms (Keasy and Short, 1990; Marriott and Marriott, 2000). Further, informal management control seems to be preferred by owner-managers in firms that lack formal management accounting. The limited or almost non-existent formal management control identified in this study also appears typical for early-phase innovative firms in accordance with Davila, Foster and Oyon (2009). According to our findings, the external auditors in these firms appear to provide accounting information needed by owner-managers about the firm, including comparisons in the form of ratios, graphs and figures. External auditors thereby appear to have a central role with respect to the innovative firms' management control. Further, our findings indicate that knowledge acquisition through auditors appears to be a relatively minor investment in management control for innovative firms.

Second, findings also show a wide range of ways in which owner-managers' use accounting and audit information in decision-making throughout the innovation process. Owner-managers use such information when making decisions related to new investments and decisions related to exploration of existing projects. Findings from this study also show that innovative firms use accounting information from auditors both to acquire knowledge about the environment and to motivate actions in specific decision situations (cf. Hall, 2010). Further, owner-managers in the study found informal management accounting useful in their communication with external financiers. These findings may be interpreted in line with the innovative firms' preference for the use of informal, social forms of control over explicit and formal management control (Collier, 2005). Nevertheless, through their use of accounting knowledge from direct contacts with external auditors, owner-managers tend to continuously and gradually learn how to develop the internal management control. Owner-managers in the innovative firms tend to apply organic control in the exploration phase by relying primarily on innovativeness but with some support from external auditors. The management control is characterised as flexible and based on the responses from knowledge acquisitions through verbal communications with external auditors. External auditors may, however, be interpreted as leading managers step by step towards the adoption of more and more formalised management control as their accounting knowledge increases. This may cause development of a more mechanistic form of management control implying a formalised reliance on accounting information for standardisation of the exploitation of innovations (cf. Davila, 2000; Ylinen and Gullkvist, 2014). The current design of reliance on informal management control may be explained by the high degree of uncertainty where the owner-managers as non-accounting experts have difficulty interpreting consequences in terms of accounting information and thus choose a strategy of external accounting knowledge acquisition. Accounting information that is externally acquired is here used to legitimise the management control of the exploration and exploitation of innovation to external stakeholders who are requesting accounting information (Davila, 2000). 
Our findings show knowledge acquired and benefits gained by innovative firms through direct contacts with auditors. The types of knowledge acquired are labelled 'comprehensive knowledge', 'diagnostic appraisal knowledge', 'contemporary business intelligence' and 'innovation investment impact knowledge' and benefits gained are referred to as 'accelerating information processing' and 'facilitating external legitimacy' of the firm's stocks and flows. These findings illuminate the nature of auditors' contribution in supporting innovative firms' value creation through the auditors' vital role in innovative firms' competence acquisition and consequently for developing ownermanagers' abilities to identify strategic gaps and thus make strategic actions that enable their businesses to thrive. It also contributes knowledge on innovative firms' internal and external preparation of financial statements, preparing the firm for strategic action and for communication to external stakeholders. Accordingly, our study adds to the competencebased theory. Although the competence-based theory proposes that a firm's competitiveness is driven by the acquisition of resources such as accounting competence, it offers little guidance in understanding why some firms prosper in the marketplace despite severe and persistent resource constraints in terms of their lack of accounting knowledge. The findings of this study support the notion that acquisitions of knowledge through external auditors enable them to overcome these constraints in management control. In fact, this study shows that innovative firms can manage their resource need by making use of resources that are not under their control. For firms in need of external competence support, a trusted external auditor acting both as a competent advisor and as a non-competitive institution becomes a key source of competence for the ownermanager in the innovative firm to make the business thrive.

All empirical studies have limitations, and our effort to understand owner-managers in innovative firms and their acquisition of accounting knowledge through direct contact with external auditors is no exception. We have identified some limitations that can serve both as qualifiers for the emergent study and warrants for further research. First, we realise that the focus on Swedish innovative firms and auditors might limit our ability to generalise our findings. However, we believe that the specific findings acquired, and especially the grounded theory, are applicable to innovative ventures in different countries in need of competence acquisition to manage the high level of uncertainty they face and to succeed, and also to auditors for providing vital accounting knowledge that can foster innovative ventures. Second, we suggest that future research can enrich the context of the present study through a broader design by including a larger number of innovative firms. We think that an increased focus on these types of studies could lead to an interesting theoretical conceptualisation about competence acquisition in innovative ventures.

Third, the present study attempts to add knowledge to the conceptualisation of auditors' role in competence acquisition, and we suggest future research to enrich the context of the present study through a broader design by including a larger number of auditors to continue on this path of theory development. We recommend strengthening the conceptual basis. The suggested approaches would enable further understanding of specific contexts and thus contribute more knowledge on complexity and heterogeneity in innovative ventures' acquisition of accounting knowledge and auditors' role in such competence acquisition. 


\section{References}

Acs, Z.J., Arenius, P., Hay, M. and Minniti, M. (2005) 2004 Global Entrepreneurship Monitor Executive Report, London Business School, UK and Babson College, MA, USA.

Baum, J.A. and Silverman, B.S. (2004) 'Picking winners or building them? Alliance, intellectual, and human capital as selection criteria in venture financing and performance of biotechnology startups', Journal of Business Venturing, Vol. 19, No. 3, pp.411-436.

Bennett, R.J. and Robson, P.J. (1999) 'The use of external business advice by SMEs in Britain', Entrepreneurship \& Regional Development, Vol. 11, No. 2, pp.155-180.

Berry, A.J., Sweeting, R. and Goto, J. (2006) 'The effect of business advisers on the performance of SMEs', Journal of Small Business, Vol. 13, No. 1, pp.33-47.

Birch, D.L. (1979) The Job Generation Process, Cambridge, MA: MIT Program on Neighbourhood and Regional Change.

Blackburn, R. and Jarvis, R. (2010) 'The role of small and medium practices in providing business support to small-and medium-sized enterprises'. Information paper April 2010, International Federation of Accountants. Retrieved May 7th, from http://www.ifac.org/system/files/ publications/files/the-role-of-small-and-mediu.pdf.

Bouwman, M.J., Frishkoff, P.A. and Frishkoff, P. (1987) 'How do financial analysts make decisions? A process model of the investment screening decision', Accounting, Organizations and Society, Vol. 12, No. 1, pp.1-29.

Camuffo, A. and Comacchio, A. (2005) 'Linking intellectual capital and competitive advantage: a cross-firm competence model for north-east Italian SMEs in the manufacturing industry', Human Resource Development International, Vol. 8, No. 3, pp.361-277.

Carraher, S. and Van Auken, H. (2013) 'The use of financial statements for decision-making by small firms', Journal of Small Business \& Entrepreneurship, Vol. 26, No. 2, pp.323-336.

Chen, F., Hope, O., Li, Q. and Wang, X. (2011) 'Financial reporting quality and investment efficiency of private firms in emerging markets', The Accounting Review, Vol. 86, No. 4, pp.1255-1288.

Clarkson, P.M. and Simunic, D.A. (1994) 'The association between audit quality, retained ownership, and firm-specific risk in US vs. Canadian IPO markets', Journal of Accounting and Economics, Vol. 17, No. 1, pp.207-228.

Collier, P.M. (2005) 'Entrepreneurial control and the construction of relevant accounting', Management Accounting Research, Vol. 16, pp.321-339.

Collis, J. and Jarvis, R. (2002) 'Financial information and the management of small private companies', Journal of Small Business and Enterprise Development, Vol. 9, No. 2, pp.100-110.

Cooper, D.J. and Morgan, W. (2008) 'Case study research in accounting', Accounting Horizons, Vol. 22, No. 2, pp.159-178.

Davila, T. (2000) 'An empirical study on the drivers of management control systems design in new product development', Accounting, Organization and Society, Vol. 25, No. 3, pp.383-409.

Davila, T. (2005) 'An exploratory study on the emergence of management control systems: formalizing human resources in small growing firms', Accounting, Organization and Society, Vol. 30, No. 3, pp.223-248.

Davila, T., Foster, G. and Oyon, D. (2009) 'Accounting and control, entrepreneurship and innovation: venturing into new research opportunities', European Accounting Review, Vol. 18, No. 2, pp.281-311.

Del Monte, A. and Papagni, E. (2003) 'R\&D and the growth of firms: empirical analysis of a panel of Italian firms', Research Policy, Vol. 32, No. 6, pp.1003-1014.

Denzin, N.K. and Lincoln, Y.S. (2000) Handbook of Qualitative Research, 2nd ed., Sage Publications, Thousand Oaks, USA.

Dunk, A.S. (2011) 'Product innovation, budgetary control, and the financial performance of firm', The British Accounting Review, Vol. 43, No. 2, pp.102-111. 
Eisenhardt, K.M. (1989a) 'Agency theory: an assessment and review', Academy of Management Review, Vol. 14, No. 1, pp.57-74.

Eisenhardt, K.M. (1989b) 'Building theories from case study research', Academy of Management Review, Vol. 14, pp.532-550.

Eisenhardt, K.M. and Graebner, M.E. (2007) 'Theory building from cases: opportunities and challenges,' Academy of Management Journal, Vol. 50, No. 1, pp.25-32.

Fellnhofer, K. (2015) 'Literature review: investment readiness level of small and medium sized companies.' International Journal of Managerial and Financial Accounting, Vol. 7, Nos. 3-4, pp.268-284.

Gibbert, M., Ruigrok, W. and Wicki, B. (2008) 'Research notes and commentaries: what passes as a rigorous case study', Strategic Management, Vol. 29, pp.1465-1474.

Gibson, B. (1992) 'Financial information for decision making: an alternative small firm perspective', The Journal of Small Business Finance, Vol. 1, No. 3, pp.221-232.

Gopalakrishnan, S. and Damanpour, F. (1997) 'A review of innovation research in economics, sociology and technology management'. Omega, Vol. 2, No. 5, pp.15-28.

Hakim, F. and Omri, A. (2009) 'Does auditor reputation reduce information asymmetry? Evidence from Tunisia.' International Journal of Managerial and Financial Accounting, Vol. 1, No. 3, pp.235-247.

Halabi, A.K., Barrett, R. and Dyt, R. (2010) 'Understanding financial information used to assess small firm performance: an Australian qualitative study', Qualitative Research in Accounting \& Management, Vol. 7, No. 2, pp.163-179.

Hall, M. (2010) 'Accounting information and managerial work', Accounting, Organization and Society, Vol. 35, pp.301-315.

Hamel, G. and Heene, A. (1994) Competence-based Competition, John Wiley \& Sons, Chichester.

Hamel, G. and Prahalad, C.K. (1990) 'The core competence of the corporation', Harvard Business Review, Vol. 68, No. 3, pp.79-91.

Hart, S. and Hultnik, E.J. (2003) 'Industrial companies evaluation criteria in new product development gates', Journal of Product Innovation Management, Vol. 20, No. 1, pp.22-36.

Healy, P.M. and Palepu, K.G. (2001) 'Information asymmetry, corporate disclosure, and the capital markets: a review of the empirical disclosure literature', Journal of Accounting and Economics, Vol. 31, pp.495-440.

Henrekson, M. and Johansson, D. (2010) 'Gazelles as job creators: a survey and interpretation of the evidence', Small Business Economics Vol. 35, No. 2, pp.227-244.

Hölzl, W. (2009) 'Is the R\&D behaviour of fast-growing SMEs different? Evidence from CIS data for 16 countries', Small Business Economics, Vol. 33, No. 1, pp.59-75.

Johansson, J. (2007) 'Sell-side analysts' creation of value: key roles and relational capital', Journal of Human Resource Costing \& Accounting, Vol. 11, No. 1, pp.30-52.

Jönsson, S. (1998) 'Relate management accounting research to managerial work'. Accounting, Organizations and Society, Vol. 23, No. 4, pp.411-434.

Keasy, K. and Short, H. (1990) 'The accounting burdens facing small firms: an empirical research note', Accounting and Business Research, Vol. 20, No. 80, pp.307-313.

Kirby, D.A. and King, S.H. (1997) 'Accountants and small firm development: filling the expectation gap', The Service Industries Journal, Vol. 17, No. 2, pp.294-304.

Kirzner, I.M. (1997) 'Entrepreneurial discovery and the competitive market process: an Austrian approach', Journal of Economic Literature, Vol. 35, pp.60-85.

Laitinen, E.K. (2009) 'Can communication and place explain managerial use of information?' Communications in Information Science and Management Engineering (CISME), Vol. 3, No. 9, pp.419-430.

Love, J.H. and Roper, S. (2002) 'Internal versus external R\&D: a study of R\&D choice with sample selection', International Journal of the Economics of Business, Vol. 9, No. 2, pp.239-255. 
Lowe, J. and Taylor, P. (1998) 'R\&D and technology purchase through licence agreements: complementary strategies and complementary assets', $R \& D$ Management, Vol. 28, No. 4, pp.263-278.

Maggina, A.G. (2009). 'Management control: a review'. International Journal of Managerial and Financial Accounting, Vol. 1, No. 3, pp.225-234.

Malmström, M. (2014) 'Typologies of bootstrap financing behavior in small ventures', Venture Capital, Vol. 16, No. 1, pp.27-50.

Malmström, M., Johansson, J. and Wincent, J. (2015) 'Cognitive Constructions of Low-Profit and High-Profit Business Models: A Repertory Grid Study of Serial Entrepreneurs', Entrepreneurship: Theory and Practice, Vol. 39, No. 5, pp.1083-1109.

Malmström, M. and Wincent, J. (2012) 'Modeling Competence Acquisition in Small Firms', International Journal of Entrepreneurship and Innovation Management, Vol. 15, Nos. 1/2, pp.131-158.

Malmström, M., Wincent, J. and Johansson, J. (2013) 'Managing competence acquisition and financial performance: An empirical study of how small firms use competence acquisition strategies', Journal of Engineering and Technology Management, Vol. 30, No. 4, pp.327-349.

March, J.G. (1991) 'Exploration and exploitation in organisational learning', Organization Science, Vol. 2, No. 1, pp.71-87.

Marriott, N. and Marriott, P. (2000) 'Professional accountants and the development of management accounting service for the small firm: barriers and possibilities', Management Accounting Research, Vol. 11, No. 4, pp.475-492.

McNichols, M.F. and Stubben, S.R. (2008) 'Does earnings management affect firms' investment decisions?', The Accounting Review, Vol. 83, No. 6, pp.1571-1603.

Miles, M.B. and Huberman, M.A. (1994) Qualitative Data Analysis: An Expanded Sourcebook, Sage, Thousand Oaks.

Oviatt, B.M. and McDougall, P.P. (1993) 'Toward a theory of international new ventures', Journal of International Business Studies (First Quarter), pp.45-64.

Ozcan, P. and Eisenhardt, K.M. (2009) 'Origin of alliance portfolios: entrepreneurs, network strategies, and firm performance', Academy of Management Journal, Vol. 52, No. 2, pp.246-279.

Paananen, M., Renders, A. and Blomkvist, M. (2016) 'Causes and Consequences of Improvements in the Information Environment for Swedish Small and Mid-Sized Firms', Accounting in Europe, Vol. 13, No. 1, pp.21-42.

Perren, L. and Grant, P. (2000) 'The evolution of management accounting routines in small businesses: a social construction perspective', Management Accounting Research, Vol. 11, No. 4, pp.391-411.

Power, M. (2003) 'Auditing and the production of legitimacy', Accounting, Organization and Society, Vol. 28, No. 4, pp.379-394.

Rossi, M. (2014) 'Capital budgeting in Europe: confronting theory with practice', International Journal of Managerial and Financial Accounting, Vol. 6, No. 4, pp.341-356.

Rossi, M. (2015) 'The role of venture capital funds in financing innovation in Italy: constraints and challenges for innovative small firms', International Journal of Globalisation and Small Business, Vol. 7, No. 2, pp.162-180.

Sanchez, R., Heene, A. and Thomas, H. (1996) Dynamics of Competence-Based Competition Theory and Practice in the New Strategic Management, Pergamon, Great Britain.

Sanchez, R. and Heene, A. (1997a) 'Managing for an uncertain future: a systems view of strategic organizational change', International studies of Management, Vol. 27, No. 2, pp.21-42.

Sanchez, R. and Heene, A. (1997b) 'Reinventing strategic management: new theory and practice for competence-based competition', European Management Journal, Vol. 15, No. 3, pp.303-317. 
Seawright, S. and Gerring, J. (2008) 'Case selection techniques in case study research: a menu of qualitative and quantitative options', Political Research Quarterly, Vol. 61, No. 2, pp.294-308.

Shane, S. and Venkataraman, S. (2000) 'The promise of entrepreneurship as a field of research', Academy of Management Review, Vol. 25, No. 1, pp.217-226.

Shawn, C. and Van Auken, H. (2013) 'The use of financial statements for decisions making by small firms', Journal of Small Business \& Entrepreneurship, Vol. 26, No. 3, pp.323-336.

Souitaris, V. (2002) 'Firm-specific competencies determining technological innovation: a survey on Greece', $R$ \& D Management, Vol. 32, No. 1, pp.61-77.

Strauss, A. and Corbin, J. (1990) Basics of Qualitative Research: Grounded Theory Procedures and Techniques, Sage Publications, Inc., Newbury Park, CA.

Tidd, J., Bessant, J. and Pavitt, K. (2005) Managing Innovation: Integrating Technological, Market and Organizational Change, 3rd ed., John Wiley and Sons, Australia.

Tzokas, N., Carter, S. and Kyriazopoulos, P. (2001) 'Marketing and entrepreneurial orientation in small firms', Enterprise and Innovation Management Studies, Vol. 2, No. 1, pp.19-33.

Venkataraman, S. (1997) 'The distinctive domain of entrepreneurship research', in Katz, J.A. (Ed.): Advances in Entrepreneurship, Firm Emergence and Growth, JAI Press, Greenwich, pp.119-138.

Yin, R.K. (1994) Case Study Research, Design and Methods, Sage Publications, Thousand Oaks.

Ylinen, M. and Gullkvist, B. (2014) 'The effects of organic and mechanistic control in exploratory and exploitative innovations', Management Accounting Research, Vol. 25, No. 1, pp.93-112.

Young, S.D. (1987) 'Financial reporting and the Austrian theory of entrepreneurship', Abacus, Vol. 23, No. 1, pp.10-17.

\section{Note}

1 All limited companies domiciled in Sweden are regulated under the Companies Act (Aktiebolagslagen (ABL) Svensk författningssamling, SFS 1975:1385). This act stipulates that all firms except the very smallest must provide an audited annual report. 